\title{
Trend of Change in Cultivated Area and Water Budget for Major Crops in Egypt using GIS and Field Survey Technique
}

\author{
Abou-Hadid, A. F. ${ }^{1}$, A. A. A. Mohamed ${ }^{2}$; M. S. M. Ahmed ${ }^{3}$ M. A. A. Abdrabbo ${ }^{4}$
}

\section{N F O \\ Received: 23 Aug 2015 \\ Accepted: 23 Sept 2015 \\ Available on-line: 12 Oct 2015 \\ Responsible Editor: M. Herdon}

\section{Keywords:}

Crop pattern - Cultivated area -

GIS - Remote sensing - Field

survey- Water budget

\begin{abstract}
A B S T R A C T
Agricultural survey, based on GIS scheme, using satellite images and topographic maps, field survey was carried out during 2008/2009 winter and 2009 summer seasons to determine the whole land cover of the Nile Delta and Valley. This was done using CLAC's recent (2006) digital shape file data for different geographic layers (Roads, railways, irrigation channels, water bodies and cultivated areas), and SPOT 5 satellite images (2007). Data show that the cultivated area of wheat was about 2.9 million feddans (4200 $\mathrm{m} 2)$ in 2008 depending on the ministry of agriculture and land reclamation (MALR) statistics, while the area of wheat in the same year according to GIS and field survey was about 2.5 million feddans. There was about $13 \%$ difference between the two concerned methods (GIS + field survey) and MALR's conventional statistical method. However, the cultivated barley area in 2008 winter season was 148 thousand feddans according to GIS + field survey data, whilst the statistical data was 181 thousand feddans. The GIS + field survey data showed that the area of cotton were decreased sharply in the season of 2009 to 250 thousand feddans compared to 284 thousand feddans with the MALR's statistical method. Water budget during winter survey for the whole crop pattern was increased from 11 billion cubic meters in 1980 to 24 billion cubic meters in 2013, while water budget during summer survey was increased from 20 billion cubic meters in 1980 to 25 billion cubic meters in 2012. The average water budget for the whole crop pattern in Nile Delta and Nile Valley was 49 billion cubic meters during 2012 /2013.
\end{abstract}

\section{Introduction}

Remote sensing refers to the activities of recording, observing, perceiving (sensing) objects or events at far away (remote) places (Canada Centre for Remote Sensing, 2003). Remote sensing techniques are widely used in agriculture and agronomy (Dorigo et al., 2007). In fact, a remote sensing image provides spatial coverage of a field, and can be used as a proxy to measure crop and soil attributes (Fitzgerald et al., 2006).

In many developing countries like Ghana, agricultural statistics utilized in different incompatible formats (tabular and graphs) that lack Geo-referencing as second level administrative aggregates. However, administrative areas are arbitrary in geographical terms varying in size, shape and time posing serious problems for mapping attempts or to interpret spatial patterns in statistical data or integrate this data with other data set (Rogana and Chen, 2004). Remote sensing plays an important role as auxiliary variable in the production of agricultural statistics, when area frame or multiple frames sample designs are used. It can, also, be used at the design level as well as at the estimator level. At the design level, the most typical use of remote sensing data is in the area frame construction and stratification. Remote sensing data can also be used to optimize the sample design where a previous ground survey is not performed; in fact, spatial characteristics (e.g. correlograms) of

\footnotetext{
${ }^{1}$ Abou-Hadid, A. F.

Ain Shams University, Cairo, Egypt

${ }^{2}$ A. A. A. Mohamed

Central Laboratory for Agricultural Climate, Agricultural Research Centre, Giza, Egypt

${ }^{3}$ M. S. M. Ahmed

Central Laboratory for Agricultural Climate (CLAC), Giza, Egypt.

${ }^{4}$ M. A. A. Abdrabbo

Central Laboratory for Agricultural Climate (CLAC), Giza, Egypt.
} 
variables of interest can be estimated on the basis of photo interpretation of remote sensing images (Quarmby et al., 1993).

The agricultural area in Egypt is composed of two parts: Nile Delta and Valley, which is the main contributor of food production, trading activities and national economy. It is also the most densely populated area in Egypt. Through the last four decades, vast areas on the desert fringes of the Nile Valley and Delta were reclaimed using mostly Nile water to add greater economic assets and relocate a significant portion of the population (El-Bagouri, 2008). The land cover changes in the Eastern Nile Delta of Egypt could be summarized as; a) the urban settlements increased considerably with high rate of annual increase ; b) slight increase in the total cultivated area while the annual rate of agricultural reclamation decreased significantly in the last few years; c) the rate of change for desert areas is stable. There is an urgent need to activate the agricultural reclamation effort to run in parallel with the urbanization processes in this area (abou-Hadid et al., 2010a). The agricultural land area is determined by climate and water availability (Khalil et al., 2011).

The Nile River is the main source for irrigation, Egypt's total water budget is estimated for about 58 billion $\mathrm{m}^{3}, 95$ per cent of which is drawn from the Nile $\left(55.5\right.$ billion $\left.\mathrm{m}^{3}\right)$, the remaining five per cent is resourced from groundwater and rainfall. Inflowing Nile water is stored in Lake Nasser and shared between Egypt and Sudan. Rain falls mostly in winter and on the Mediterranean coast and does not exceed 130-170 mm. Excerpt from (Egypt`s $2^{\text {nd }}$ National Communication to the United Nations Convention on Climate Change, 2010). The per capita water share is $815 \mathrm{~m}^{3}$ per year (Mohamed A. A. A., 2012). Agriculture uses 80 percent of Egypt's water resources. Egypt ranks among the lower 10 percent of countries in the region in terms of water efficiency in irrigation, with only limited advancement over the past ten years (Egypt National Competitiveness Council, Egyptian National Competitiveness Report, 2009).

Based on the above background, and due to the water is a limit factor which controls land reclamation process in Egypt, the main objective of the current study is to compare the remote sensing and field survey technique during 2008/2009 winter and 2009 summer seasons with the conventional statistical method used by MALR. In addition to estimating the water budget of cultivated areas in Nile Delta and Valley during winter and summer seasons.

\section{Materials and methods}

\subsection{Methodology}

Suitable methodology according to (abou-Hadid et al., 2010 b) is developed for estimating crop area by integrating remote sensing and GIS based on survey approach. Area frame surveys were common approaches to gather land cover data. In contrast to mapping approaches, area frame sampling was a statistical method. Based on the visual observation of sampling geo-referenced points, area estimates were computed and used as a valid generalization without studying the entire area under investigation.

The survey concerning the estimation of yield for the major crop was carried out by cutting small samples in the field. The samples cover the whole Nile valley and the delta, with an observed area of about $35000 \mathrm{~km}^{2}$ and distance from South to North of about $1000 \mathrm{~km}$. Digital topographic maps 1:5000 and SPOT5 satellite Images were used, $2.5 \mathrm{~m}$ resolution, Ortho-rectified (DTM). The survey used the WGS84, Universal Transverse Mercator $36 \mathrm{~N}$, (parameter are given hereafter).

Three thousands site were visited during the winter crop survey, the samples could be constituted of a sub-set of these sites and one point will be designed in each of the selected sites. If this point is wheat, it will be included in the yield sample and visited at harvest time. The sub sample is defined as points of observation, $250 \mathrm{~m} \times 250 \mathrm{~m}$ apart; there are 10 points of observations which are called points, they are located in two lines East-West of 5 points. In the winter survey of 2009, the main results were field crop land cover of the major area in the Nile valley and Nile Delta, its cover is about $48 \%$ of the total area. Furthermore, the field crops cover is about $79 \%$ of the total cultivation area, the wheat and clover (Barseem) covered about $75 \%$ of the total field crop area. 


\subsubsection{Area or point sampling}

The decision to sub_ sample the segment area through a grid of points is straight forward when looking to the structure of variance (variance between segments and variance between points within segments). In all our sampling simulation, the component of variance related to the second stage rarely reached $5 \%$ of the total variance.

For the above reasons, the sampling plan adopted consists of one systematic square grid 2 $(1 \times 1.5 \mathrm{Km})$ and rectangular segments of $2 \times 5$ points $250 \mathrm{~m}$ apart (Abou-Hadid et al., $2010 \mathrm{~b}$ ). This imposes, due to the absence of replicates, an approximate estimation of variance through the differences between neighbouring sampling units (Cochran, 1977).

The survey started on the $15^{\text {th }}$ January, 2009: the sample covers the whole Nile valley and the delta, the observed area is about $35000 \mathrm{~km}^{2}$ and the distance from South to North is about $1000 \mathrm{~km}$ Fig. (1). One hundred surveyors, each visited a 1/100 of this area, and a set of supervisors to manage the network of surveyors. A supervisor covers a regional zone and manages about ten or twelve surveyors. These ratios were globally maintained in 2009.

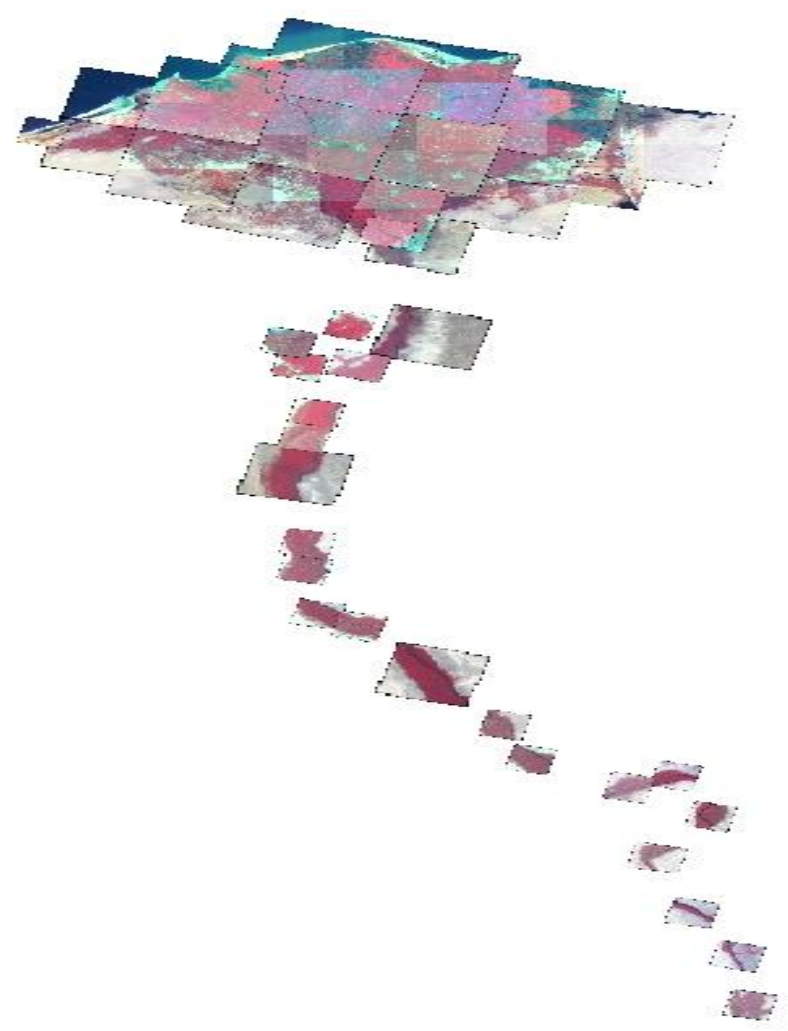

Figure 1. Satellite image of the Nile Delta and Nile Valley

\subsubsection{Determine field survey sites}

The sampling plan is systematic and has two levels Fig. (2): Primary Sampling Unit (PSU) and Secondary Sampling Unit (SSU). The primary sampling Unit is based on a regular grid $1 \mathrm{x} 1.5 \mathrm{~km}$ coming from the Egyptian cadastral maps 1 x $1.5 \mathrm{~km}$. The cadastral maps were elaborated by the Egyptian Survey Authority (ESA) and have been updated by the Ministry of Agriculture using aerial photographs in the year 1985. The PSU represents an area of around $1.5 \mathrm{~km}^{2}$. The index grid of the maps has been drawn over the full Egyptian territory while the systematic random has been carried out in chosen one out of ten sheets according to the following algorithm. Sx, $y=$ ith (modulo 5) column on the jth row, and $(i+2)$ the $(\bmod 5)$ column on the $(j+2)$ th row.

The following examples show the geo-referenced Grid $1 \times 1.5 \mathrm{~km}$ covering the entire Delta and Nile Valley including around a buffer zone in order to take into account a potential agriculture extension over the desert. The coordinate system used for all geographic data were downloaded on 
GPS devices to every surveyor (100 surveyor covered all Nile delta and Nile valley, National grid Egyptian Transverse Mercator (Red Belt). The survey used the WGS84, Universal Transverse Mercator 36 N, (parameter are given hereafter). (Abou-Hadid et al., 2010 b).

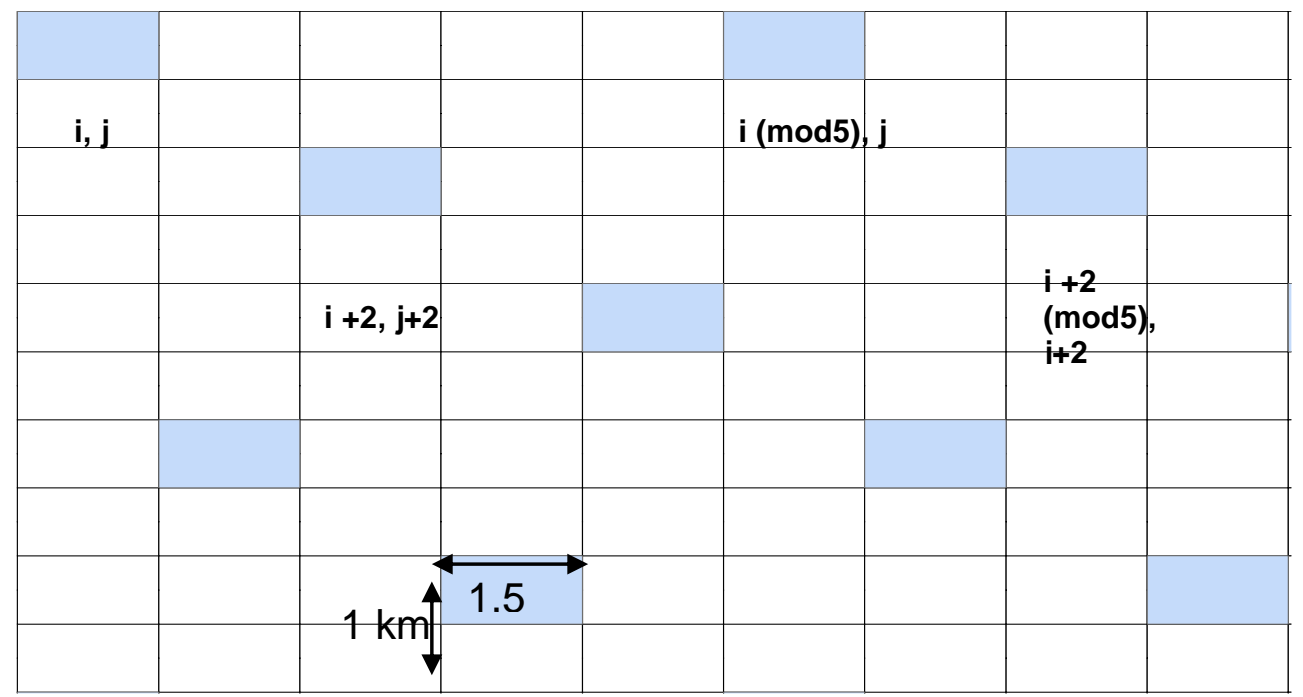

Figure 2. Grid of cadastral maps 1 x $1.5 \mathrm{~km}$

\subsubsection{Determine of sub site (Points)}

The SSU's are defined as points of observation, $250 \mathrm{~m} \times 250 \mathrm{~m}$ apart; there are 10 points of observation, which are called points. They are located in two lines East-West of 5 points. From the previous grid of selected sites which came from the previous project, some steps were implemented in order to obtain the final grid of 10 point. The different steps are described next.

\subsubsection{Nomenclature}

The design of the nomenclature is based on Classification system for land cover and land use (Eurostat, 2001 and Abou-Hadid et al., 2010 b). Various existing national and international classification systems have been analysed to establish best practice for the construction of a classification system in order to be used in the framework of LUCAS.

The main points which were the object of analysis and choices are as follows:

- The definition of Land (extended to inland water), of Land Cover (above the earth's surface);

- The observation unit: a circle of $3 \mathrm{~m}$ of diameter except in case of heterogeneous areas or permanent crops;

- The separate registration of multiple use/cover in order to avoid mixed classes;

- The treatment of points on limits and the use of ortho photography;

- The documentation of the classes in terms of definition, list of inclusions and exclusions, compatibility between land cover and land use; and

- The correspondence with existing national or international classification systems. 


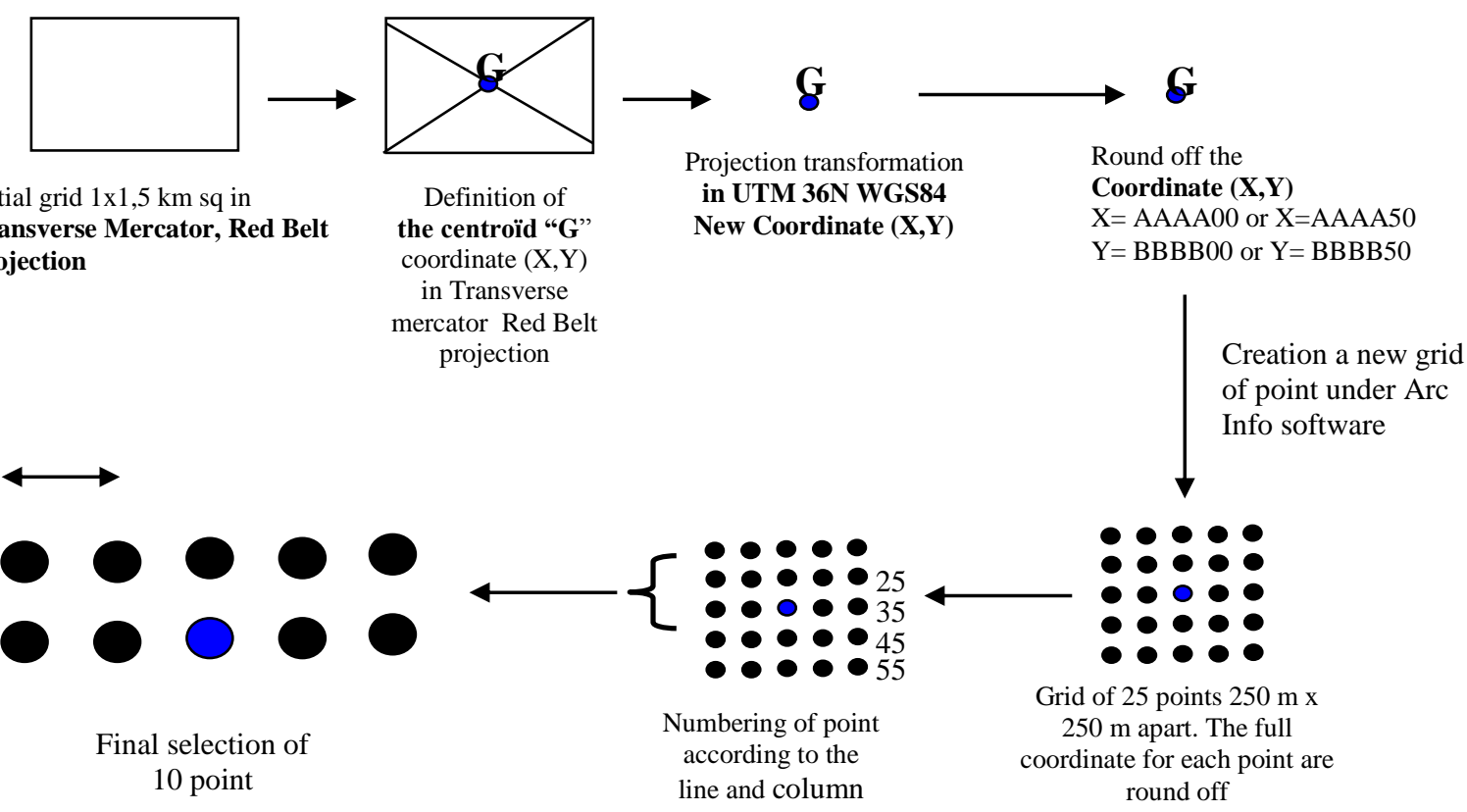

Figure 3. Methodology of the selection of sub - sites.

\subsubsection{Estimators}

Three main types of estimators will be used in function of the variable of interest was the area estimates: point sampling has the characteristic of having a sampling probability proportional to the size of the selected unit. For area estimates of land cover classes, this has the major interest via which an unbiased estimate is obtained through the multiplication of the area of interest by the percentage of points falling in the category of interest. (Abou-Hadid et al., $2010 \mathrm{~b}$ )

\subsection{Estimation of irrigation water requirements (IWR)}

Two steps were used to estimate the irrigation water requirements for the major cultivated crops in Nile Delta and Nile Valley during winter and summer seasons. The first step was the estimation of the evapotranspiration (ETo) by using Food and Agricultural Organization (FAO) Penman- Monteith (PM) procedure, FAO 56 method, presented by (Allen et al., 1998). In this method, ETo is expressed as follows:

$$
E T_{o}=\frac{0.408 \Delta\left(R_{n}-G\right)+\gamma \frac{900}{T+273} u_{2}\left(e_{s}-e_{a}\right)}{\Delta+\gamma\left(1+0.34 u_{2}\right)}
$$

Where: ETo is the daily reference evapotranspiration $\left(\mathrm{mm} \mathrm{day}^{-1}\right), \mathrm{R}_{\mathrm{n}}$ is the net radiation at the crop surface $\left(\mathrm{MJ} \mathrm{m}^{-2}\right.$ day $\left.^{-1}\right), \mathrm{G}$ is the soil heat flux density $\left(\mathrm{MJ} \mathrm{m}-2\right.$ day $\left.^{-1}\right), \mathrm{T}$ is the mean daily air temperature at $2 \mathrm{~m}$ height $\left({ }^{\circ} \mathrm{C}\right), \mathrm{U}_{2}$ is the wind speed at $2 \mathrm{~m}$ height $\left(\mathrm{m} \mathrm{s}^{-1}\right), \mathrm{e}_{\mathrm{s}}$ is the saturation vapor pressure $(\mathrm{kPa}), \mathrm{e}_{\mathrm{a}}$ is the actual vapor pressure $(\mathrm{kPa}), \Delta$ is the slope of vapor pressure curve $\left(\mathrm{kPa}^{\circ} \mathrm{C}^{-1}\right)$ and $\gamma$ is the psychometric constant $\left(\mathrm{kPa}^{\circ} \mathrm{C}^{-1}\right)$.

The second step was the estimation of irrigation requirements for each crop by using the following equation according to $(\mathrm{FAO}, 56)$ as follows:

Where:

$$
\mathrm{WR}=\mathrm{ETo} \mathrm{x} \text { KC } \mathrm{x} \text { IE }
$$

$\mathrm{WR}=$ Water requirements for cultivated crop.

$\mathrm{ETo}=$ Reference evapotranspiration of agro-climatic region .

$\mathrm{KC}=$ Crop coefficient.

$\mathrm{IE}=$ irrigation efficiency for the irrigation system.

Trickle irrigation method was supposed for the irrigation of vegetable and orchards crops and the efficiency of irrigation system was $80 \%$, whereas flood irrigation method was supposed for the irrigation of field crops and the efficiency of irrigation system was $60 \%$. 


\section{Results and discussion}

\subsection{Winter Survey}

The winter crop area survey was carried out during January and February at 2009 by the surveyors' teams. The surveyors visited 2700 sites, spread all over the Nile valley, the delta, and its extensions. The observed zone represents $52882 \mathrm{~km}^{2}$. The surveyors noted the cover of the land for 31500 spots in the country and it was completed with 3500 spots, located inside large towns or at the boundaries (mainly desert and sea), which were photo-interpreted. Clover (Barseem) and wheat were the major crops in the winter survey, occupied about 4.5 million feddans of the total agricultural area during the 2008 winter season depending on GIS and field survey. The total cultivation area was almost 7.6 million feddan at 2008/2009 winter season. Wheat and Barseem occupied about 59\% of the total cultivated area during 2008/2009 winter survey and $75 \%$ of the total occupied area of field crops based on the results of GIS + field survey data (Fig. 4).

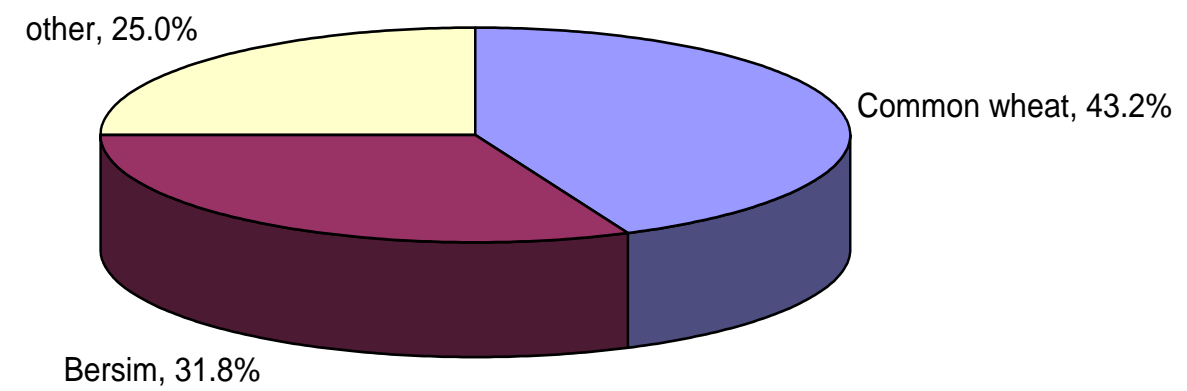

Figure 4. Percentage of main crops in the Nile Delta and Nile Valley during 2008/09 winter survey

Wheat occupies approximately 2.5 million feddans at 2008 winter season. The area of wheat increased from 1.3 million feddans in 1980 to 3.4 million feddans in 2013. The cultivated area with wheat reached about 2.9 million feddans in 2008/2009 season depending on the ministry of agriculture and land reclamation (MALR) statistics, while the area of wheat in 2008 depending on the GIS+ field survey data was 2.5 million feddans. There is about $13 \%$ difference between the two records as shown in Table (1).

The area occupied by barley increased from 95 thousand feddans in 1980 to 230 thousand feddans in 2000 season, there was about $150 \%$ increase in barley area, while the area decreased in 2008 depending on statistical analysis of MALR and GIS+ field survey data. The total area occupied by barley in 2008/2009 winter season was 148 thousand feddans according to GIS+ field survey data, while the MALR data was 181 thousand feddans (Fig. 5). The area which was decreased in 2013 reached 78.6 thousand feddans.

The total area occupied by Faba-beans increased from 244.7 thousand feddans in 1980 to reach about 344 thousand feddans in 2000 season, while the area of Faba-bean was decreased again at 2008 season to become 190 thousand feddans depending on the statistical of MALR. But the area of Fababean is increased again in 2008 winter season depending on GIS+ field survey data to reach about 300 thousand feddans, with the same record in 2000 winter season.

The area cultivated by potato crop increased from 110 thousand feddans in 1990 to 252 thousand feddans in 2008winter season depending on remote sensing data. The same trend was true with tomato crop; the total area of tomato was 136 thousand feddans in the 1980 winter season to reach about 218 thousand feddans in 2008 winter season. 
Table 1. Winter survey for major crops of the Nile Delta and Nile Valley from 1980 to 2013 in Feddans

\begin{tabular}{|c|c|c|c|c|c|c|}
\hline Crops & $1980^{*}$ & $1990^{*}$ & $2000^{*}$ & $2008^{*}$ & $2008^{* *}$ & $2013^{*}$ \\
\hline Clover (barseem) & 1721655 & 1660333 & 1810387 & 1619769 & 1926400 & 1386508 \\
\hline Wheat & 1326179 & 1954696 & 2463265 & 2920384 & 2547100 & 3377876 \\
\hline Barley & 95528 & 191669 & 230373 & 181980 & 148950 & 78679 \\
\hline Faba-beans & 244746 & 344643 & 306626 & 190464 & 302900 & 118873 \\
\hline Sugar beet & - & 34088 & 135623 & 257667 & 197100 & 460488 \\
\hline Sugar cane & 252481 & 263190 & 311986 & 258000 & 252600 & 325742 \\
\hline Potato & - & 110188 & 63459 & 148969 & 252600 & 195773 \\
\hline Tomato & 135920 & 158273 & 177225 & 217887 & 213600 & 201686 \\
\hline Other vegetables & 136534 & 180069 & 452414 & 325827 & 483000 & 366237 \\
\hline Orchards & 360995 & 866472 & 1019259 & 1279017 & 1490586 & 1541781 \\
\hline Total & $\mathbf{4 2 7 4 0 3 8}$ & $\mathbf{5 7 6 3 6 2 1}$ & $\mathbf{6 9 7 0 6 1 7}$ & $\mathbf{7 3 9 9 9 6 4}$ & $\mathbf{7 8 1 4 8 3 6}$ & $\mathbf{8 0 5 3 6 4 3}$ \\
\hline
\end{tabular}

* Data collected from MALR.

** GIS + field survey data.

There were no big differences between MALR records and GIS+ field survey data for tomato areas during the 2008 winter season.

Regarding the area occupied with orchard trees, the orchard were steadily increased from 1980 till 2013 seasons. The area covered with orchards was 360 thousand feddans in 1980, to reach about one million feddans in 2000 season, 1.3 million feddans in 2008 season and 1.5 million feddans in 2013 season. There were differences between MALR and remote sensing records during 2008. The result of the GIS+ field survey data in winter 2008 recorded about 200 thousand feddans more than the Ministry of Agriculture Statistical records maybe due to more accurate data by using remote sensing and field survey especially at new reclaimed lands.

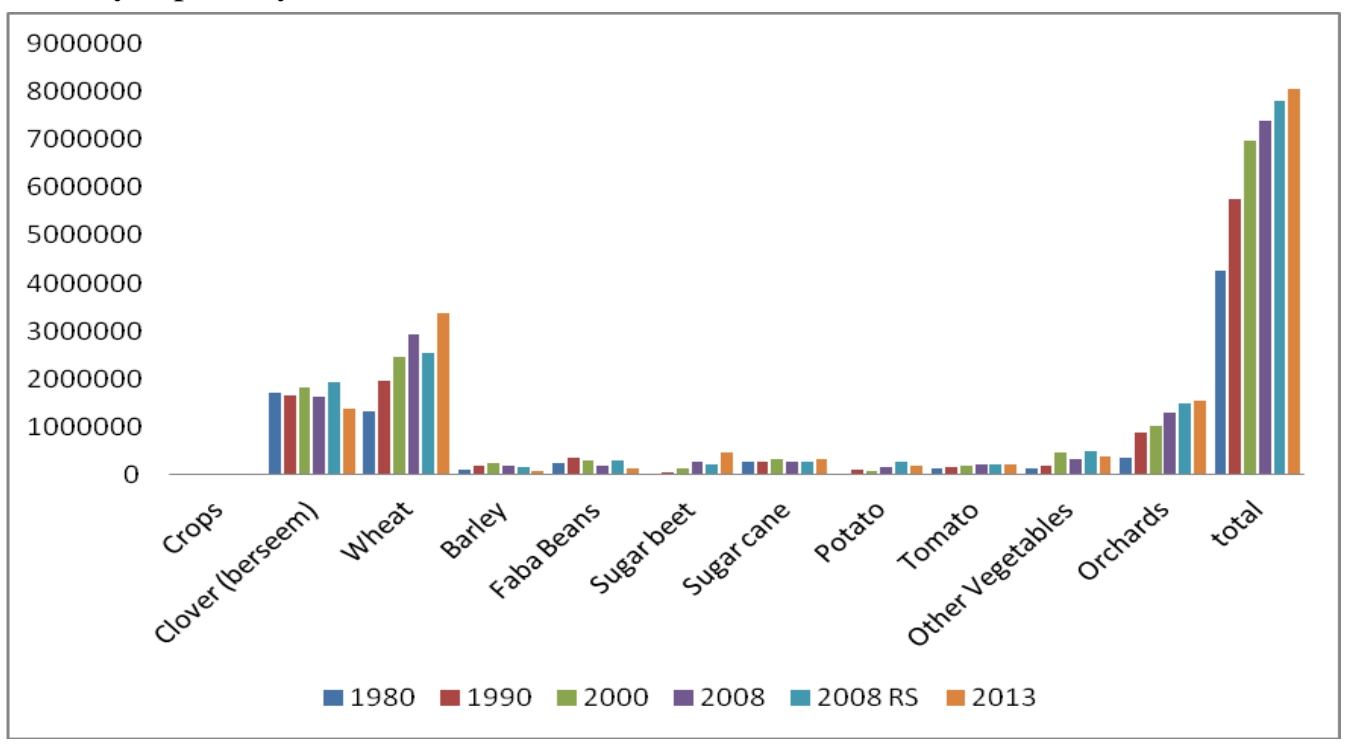

Figure 5. Area of the main crops in the Nile Delta and Nile Valley from 1980 to 2013 winter survey.

\subsection{Summer Survey}

The summer crop area survey was carried out from mid June to the end of July by CLAC. The surveyors visited 2000 sites, spread all over the Nile Valley, the Delta and its extensions. The observed zone represents $42900 \mathrm{~km}^{2}$. The sites out of agriculture lands during the winter survey were excluded from the summer survey (desert, towns and wetland). Rice and maize are the main summer crops; meanwhile areas dedicated to cotton are shrinking. The barseem item corresponds to areas dedicated to seeds and has not already cropped. Agricultural bare land represents about $11 \%$ of the agricultural land, on these areas the winter crop has been already harvested and the area has not yet 
been sown; for the summer crop rice and maize are the major crops in the summer, there were occupying about 3.4 million feddans of the total agriculture area during the 2009 summer season depending on satellite image and field survey done by (CLAC). The total cultivation area was almost 6.6 million feddans in 2009 summer season. Maize and Rice are $87 \%$ of the total area occupied by field crops during the 2009 season depending on GIS+ field survey data (Fig. 6).

Maize occupied about 1.6 million feddans in 2009 summer season depending on GIS+ field survey technique (Table 2). The area of maize was stable from 1980 till 2000. While the total cultivated area decreased in 2013 and reached 1.8 million feddans.

The area occupied by rice increased from 970 thousand feddans in 1980 to 1.6 million feddans in 2000, there were about 57\% increase in rice area, while the area decreased in 2012 depending on MALR data to reach 1.47 million feddans and according to GIS + field survey data. The total area occupied by rice in 2009 summer season was 1.8 million feddans, while the MALR data was 1.36 million feddans as showed in table (2).

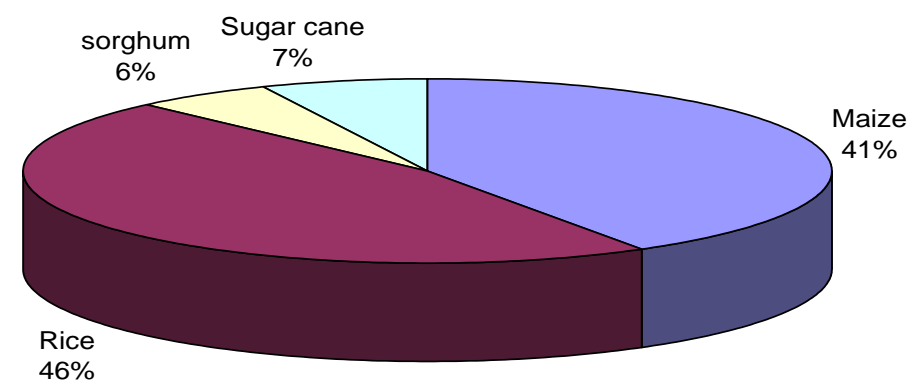

Figure 6. Percentage of main crops in the Nile Delta and Nile Valley during 2009 summer survey

The total area occupied by sorghum was decreased from 410 thousand feddans in 1980 to 386 thousand feddans in 2000. Moreover, the area of sorghum decreased again in 2009 season to 333 thousand feddans depending on the MALR. The area of sorghum was sharply decreased in 2009 summer season depending on GIS + field survey data to reach about 222 thousand feddans.

Regarding the area cultivated by tomato crop increased from 195 thousand feddans in 1980 to reach 288 thousand feddans 2000 at summer season depending on MALR data. The area was decreased in 2009 summer season to become 270 thousand feddans and 255 thousand feddans, depending on MALR data and GIS+ field survey data respectively.

Regarding the area occupied with the cotton crop during the period from 1980 till 2012, data shows that the area cultivated with cotton crop was decreased from 1.2 million feddans in 1980 to become 333 thousand feddans in 2012 summer season, this decrease was about 73\% of the total cotton area. The GIS+ field survey data showed that the area of cotton was decreased sharply at 2009 season to become about 250 thousand feddans, whereas, the cotton area was 284 thousand feddans in 2009 season. 
Table 2. The results of the Nile Delta and valley from 1980 to 2012 summer survey for major crops in feddans

\begin{tabular}{|c|c|c|c|c|c|c|}
\hline Crops & $1980 *$ & $1990 *$ & $2000 *$ & $2009 *$ & $2009 * *$ & $2012 *$ \\
\hline Maize & 1905809 & 1975815 & 1950289 & 1721018 & 1599000 & 1839206 \\
\hline Sorghum & 410082 & 319234 & 386980 & 333189 & 222000 & 337325 \\
\hline Rice & 970096 & 1037461 & 1569765 & 1369238 & 1809000 & 1472139 \\
\hline Tomato & 195800 & 212704 & 287932 & 270321 & 255000 & 208068 \\
\hline Cotton & 1244526 & 993047 & 518319 & 284434 & 249000 & 333360 \\
\hline Sugar cane & 252481 & 263190 & 311986 & 316712 & 258000 & 325742 \\
\hline Orchards & 360995 & 866472 & 1019259 & 1407071 & 1491250 & 1541781 \\
\hline Other Vegetable & 219592 & 390920 & 598146 & 849721 & 748000 & 829688 \\
\hline Total & 5559381 & 6058843 & 6642676 & 6551704 & 6631250 & 6887309 \\
\hline \multicolumn{7}{|c|}{$\begin{array}{l}\text { Data collected from MALR } \\
* \text { GIS + field survey data }\end{array}$} \\
\hline \multicolumn{7}{|l|}{8000000} \\
\hline \multicolumn{7}{|l|}{7000000} \\
\hline \multicolumn{7}{|l|}{6000000} \\
\hline \multicolumn{7}{|l|}{5000000} \\
\hline \multicolumn{7}{|l|}{4000000} \\
\hline \multicolumn{7}{|l|}{3000000} \\
\hline \multicolumn{7}{|l|}{2000000} \\
\hline \multicolumn{7}{|l|}{1000000} \\
\hline \multirow[t]{2}{*}{0} & ה & P & . & & & $\partial$ \\
\hline & — 1980 & - 1990 & $00-2009$ & 2009 R. S. & 2012 & \\
\hline
\end{tabular}

Figure 7. Area of the main crops in the Nile Delta and Nile Valley regions from 1980 to 2012 by summer survey

\subsection{Comparison between GIS + field survey data and MALR statistics}

Data in figures 8, 9 and 10 showed the comparison between field survey and MALR statistics for the Nile Delta, Middle and Upper Egypt regions, respectively. Fig. 8 shows a matching between the data from field survey and MALR statistics for most governorates except Behira and Ismailia, those two governorates have a bigger desert extension area than the others, perhaps MALR statistics don't have enough accessibility to these areas and then the total cultivated area was lower than the real cultivated area. The same results are true for the Middle and Upper Egypt regions; field survey revealed that Giza and Minia governorates have different cultivated area compared to MALR statistics while Beni-Suif and Fyoum governorates are matched with the MALR statistics. Finally, Upper Egypt data obtained from field survey for Asyut, Qena and Aswan governorates was higher than MALR statistics. Generally, most governorates with desert extension have lower total cultivated areas by MALR statistics than field survey data. The same results were obtained by Abou-Hadid et al., (2010b). 


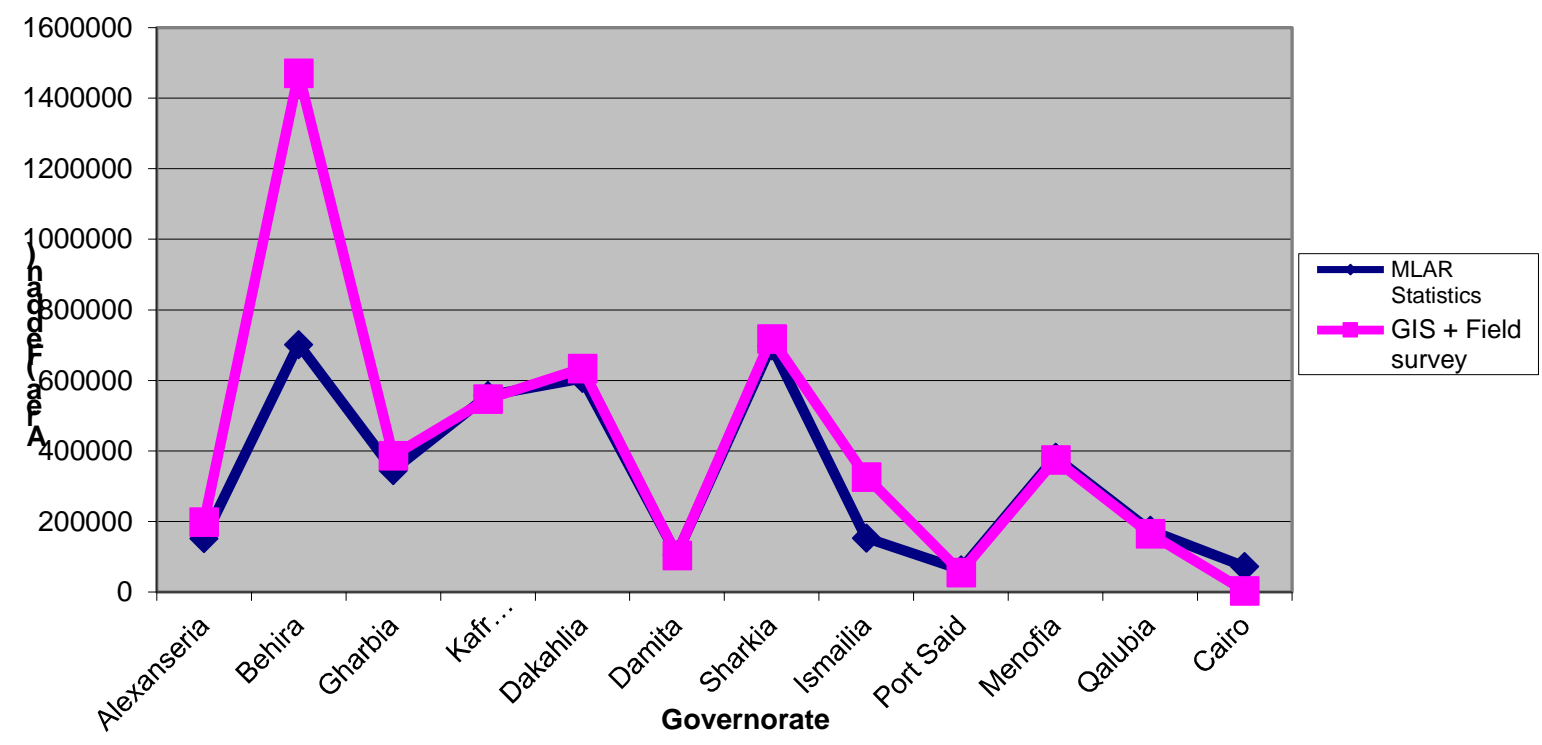

Figure 8. Comparison between total crop area of the Nile Delta governorates under field survey and MALR statistics

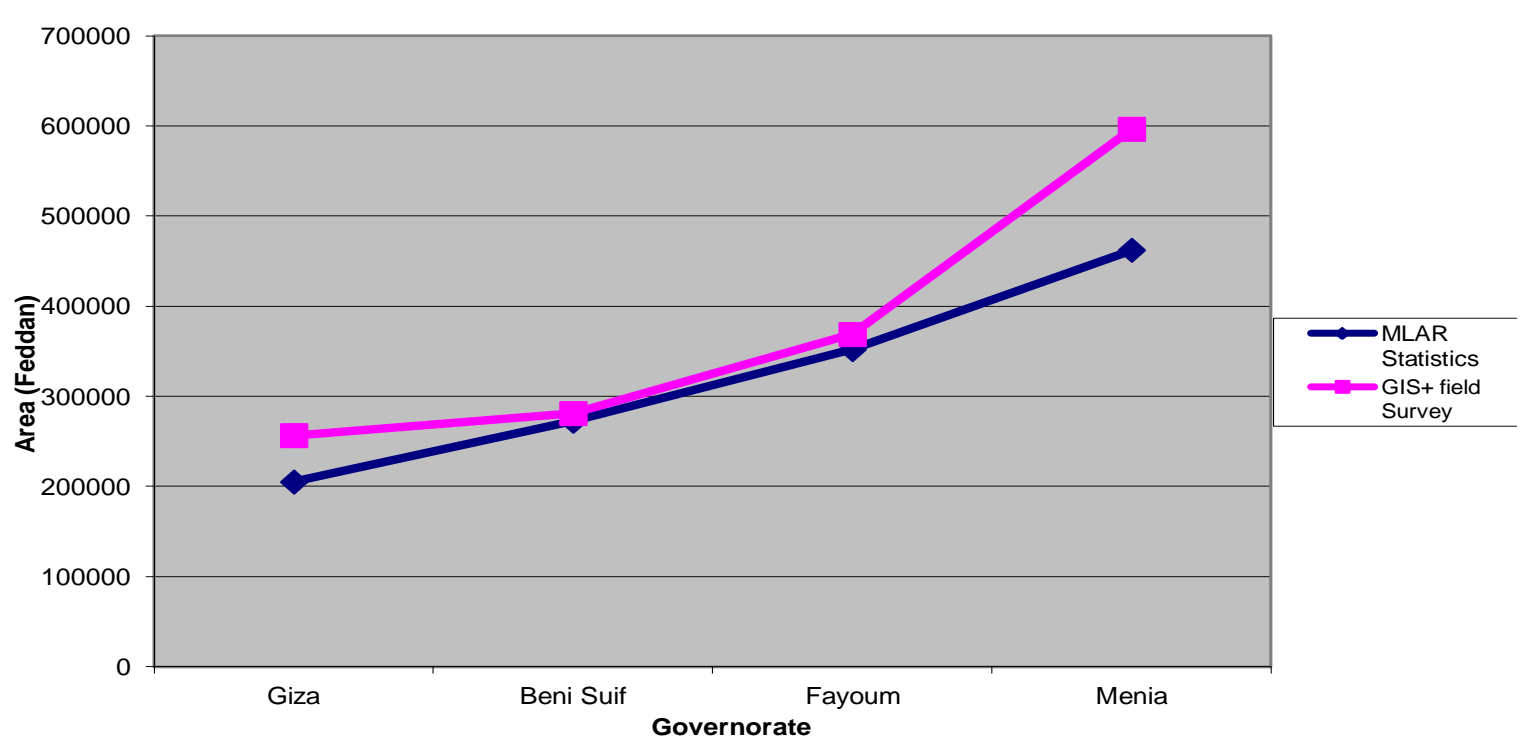

Figure 9. Comparison between total crop area of different governorates of Middle Egypt under field survey and MALR statistics. 


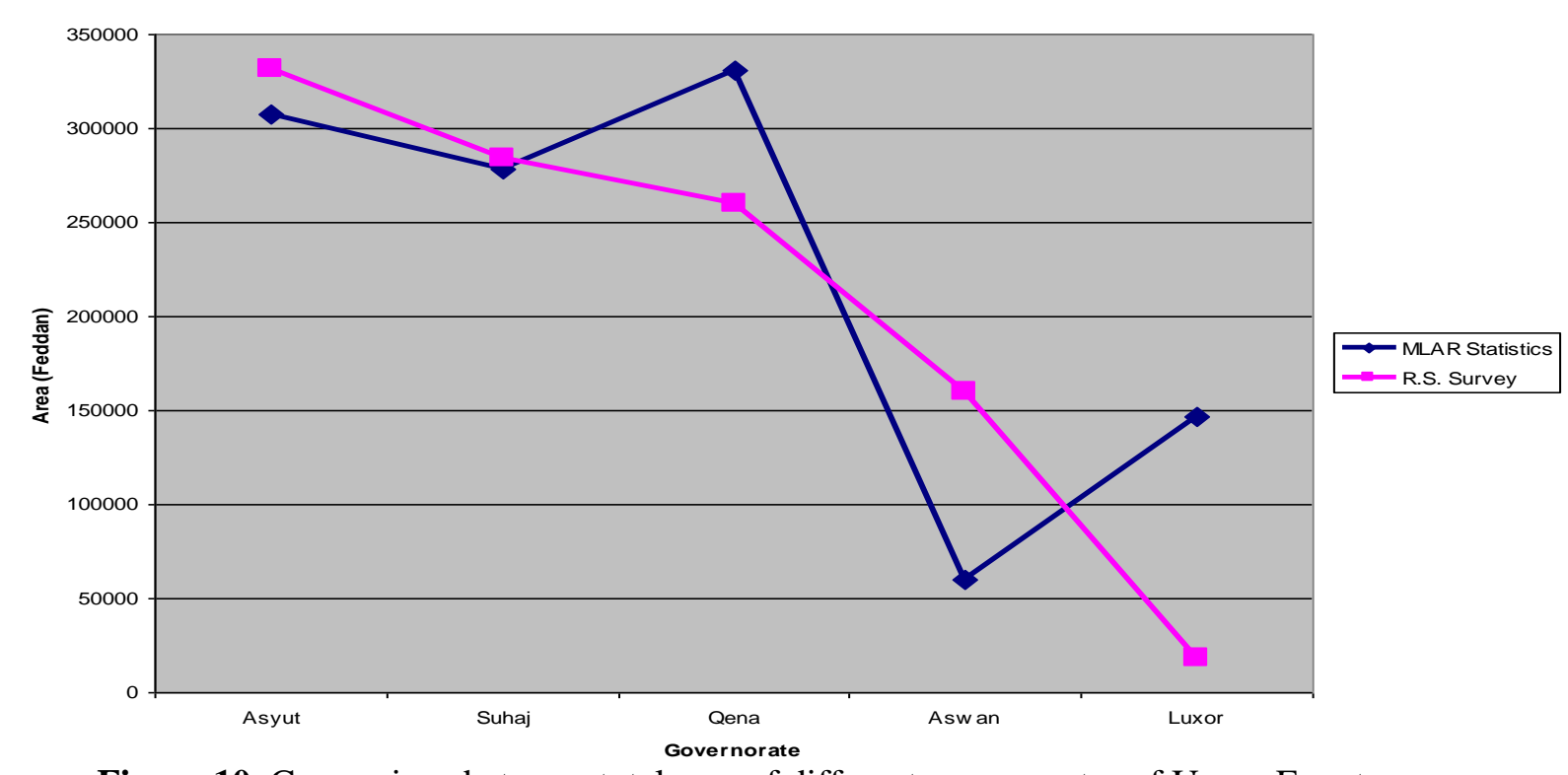

Figure 10. Comparison between total area of different governorates of Upper Egypt under field survey and MALR statistics.

\subsection{Water budget}

\subsubsection{Irrigation water requirements}

Data in Table 3 and Figure 11 show the estimated annual irrigation water requirements (IWR), cubic meter (CM) per feddan, for different cultivated crops during winter season, summer season and for permanent crops, i.e. sugar cane and orchards. Regarding to irrigation water consumption of winter crops, sugar beet was the highest in water consumption during winter, (2660 CM per feddan), followed by wheat (2334 CM per feddan). On the contrary, faba-bean was the lowest in water consumption (1398 CM per feddan). Generally, summer crops were higher in irrigation water consumption than winter crops, due to the higher average air temperature degree in summer months compared to winter months. This increase led to the increase in evapotranspiration.

Furthermore, Rice was the most water consumption crop, (5074 CM per feddan), while vegetables were the lowest irrigation consumption crops. As for permanent crops, data show that sugar cane was higher in water consumption, (7796 CM per feddan), than orchards trees (5277 CM per feddan) may be due to the use of modern irrigation system, such as trickle or sprinkler irrigation systems, in new reclaimed land in the dessert areas, whereas sugar cane was irrigated using old flood irrigation system.

Table 3. Irrigation water requirements for cultivated crops in Nile Delta and Valley

\begin{tabular}{|c|c|c|c|c|c|}
\hline \multirow[b]{2}{*}{ Winter crops } & IWR & \multirow[b]{2}{*}{ Summer crops } & IWR & \multirow[b]{2}{*}{$\begin{array}{l}\text { Permanent } \\
\text { crops }\end{array}$} & IWR \\
\hline & $\begin{array}{l}(\mathrm{CM} / \\
\text { feddan })\end{array}$ & & $\begin{array}{l}(\mathrm{CM} / \\
\text { feddan })\end{array}$ & & $\begin{array}{l}(\mathrm{CM} / \\
\text { feddan })\end{array}$ \\
\hline Clover (barseem) & 1881 & Maize & 2699 & Sugar cane & 7796 \\
\hline Wheat & 2334 & Sorghum & 2372 & Orchards & 5277 \\
\hline Barley & 1810 & Rice & 5074 & & \\
\hline Faba-beans & 1398 & Cotton & 4127 & & \\
\hline Sugar beet & 2660 & Tomato & 2366 & & \\
\hline Potato & 1769 & Other vegetables & 2302 & & \\
\hline Tomato & 1938 & & & & \\
\hline Other vegetables & 2246 & & & & \\
\hline
\end{tabular}




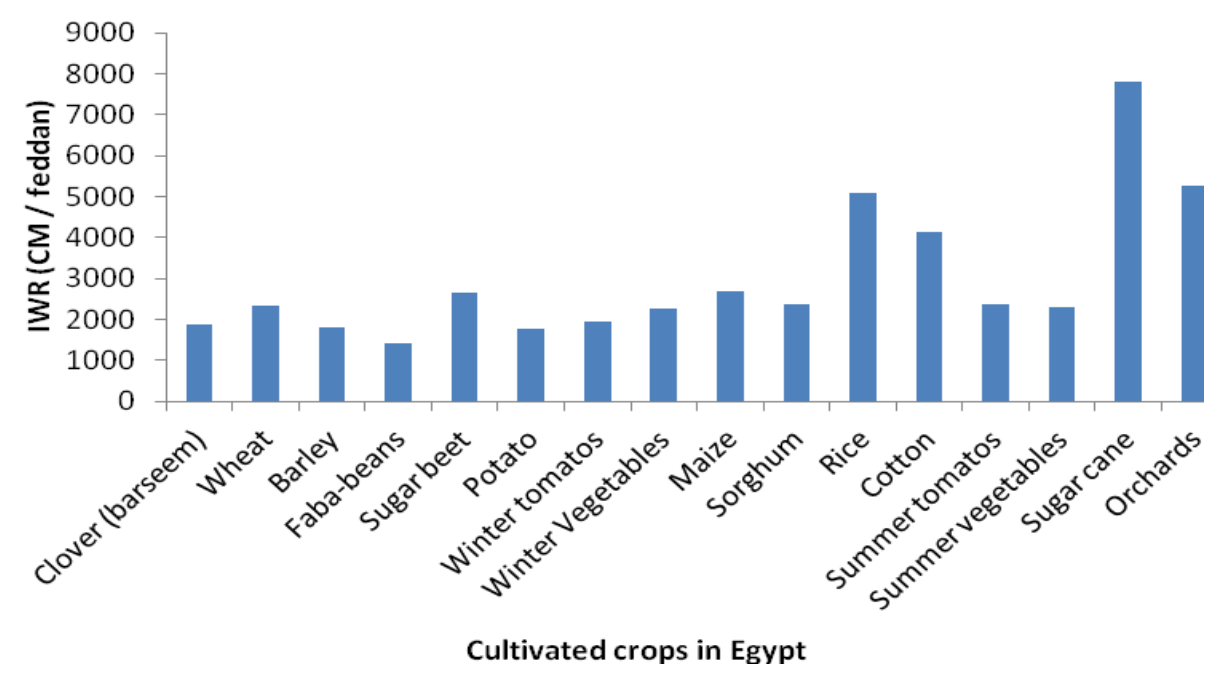

Figure 12. Irrigation water requirements (CM/ feddan) for different crops in Nile Delta and Valley

\subsubsection{Water budget for winter season}

Data in Table 4 and Fig. 12 show the trend of total water budget for cultivated areas from 1980 to 2013 winter survey. The total water budget was increased continuously throughout the studied period, the amount of irrigation water increased from 11 billion cubic meters (BCM) in 1980 to 24 BCM in 2013 due to the increase of cultivated areas and governmental land reclamation efforts. On the other hand, there was a slight difference in water budget in 2008 between GIS + field survey and MALR statistics. Water budget based on GIS + field survey was $22.5 \mathrm{BCM}$ whereas, the water budget was 21 BCM according to MALR statistics. This difference may be due to the high accuracy of the methodology used in GIS+ field survey. In 2013 winter survey, despite that sugarcane consumed much water per feddan, $(7796 \mathrm{CM})$, the irrigation water consumption for orchards trees was greater ,because of the increase cultivated area of orchards trees, (1542 thousand feddans) compared to the cultivated area of sugarcane, (326 thousand feddans).

Table 4. Irrigation water budget (MCM) for cultivated area in winter survey

\begin{tabular}{|c|c|c|c|c|c|c|}
\hline Crops & $1980^{*}$ & $1990^{*}$ & $2000^{*}$ & $2008^{*}$ & $2008 * *$ & $2013^{*}$ \\
\hline Clover (barseem) & 3238 & 3123 & 3405 & 3046 & 3623 & 2608 \\
\hline Wheat & 3096 & 4563 & 5750 & 6817 & 5946 & 7885 \\
\hline Barley & 173 & 347 & 417 & 329 & 270 & 142 \\
\hline Faba-beans & 342 & 482 & 429 & 266 & 423 & 166 \\
\hline Sugar beet & 0 & 91 & 361 & 685 & 524 & 1225 \\
\hline Sugar cane & 1968 & 2052 & 2432 & 2011 & 1969 & 2539 \\
\hline Potato & 0 & 195 & 112 & 263 & 447 & 346 \\
\hline Tomato & 263 & 307 & 343 & 422 & 414 & 391 \\
\hline Other vegetables & 307 & 404 & 1016 & 732 & 1085 & 822 \\
\hline Orchards & 1905 & 4572 & 5378 & 6749 & 7866 & 8136 \\
\hline Total & 11292 & 16135 & 19644 & 21323 & 22566 & 24261 \\
\hline
\end{tabular}

* Data calculated using cultivated area from MALR

** Data calculated using cultivated area from the GIS+ field survey data. 
Wheat ranked as the second irrigation water consumption crop in winter survey, because of the government concern to increase wheat cultivation area to cope with the people's demand and rapid increase in human population. Barley and vegetables, including tomatoes are the lowest water consumption when compared to other crops. These results are due to the use of high efficient modern irrigation systems. As for barley crop, it is not highly affected by irrigation water and is able to resist water deficiency.

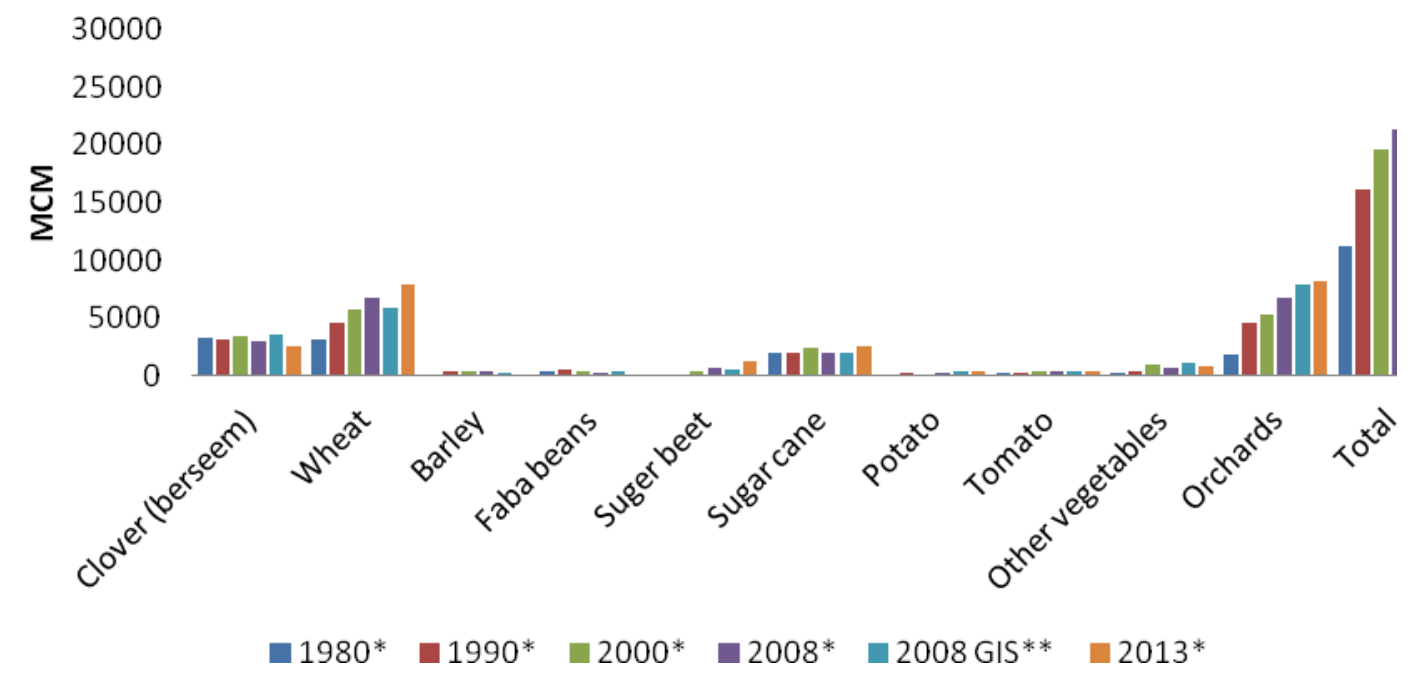

Figure 12. Water budget for cultivated crops in Nile Delta and Valley from 1980 to 2013 during the winter survey

\subsubsection{Water budget for summer season}

Data in Table 5 and Figure 13 show the water budget for cultivated area from 1980 to 2012 summer survey. The total water budget was increased continuously throughout the period of the survey; the amount of water irrigation increased from $20 \mathrm{BCM}$ in 1980 to $25 \mathrm{BCM}$ in 2012. This result is due to the annual increase of cultivated land areas because of land reclamation effort. On the other hand, there was a slight difference in water budget between 2008 GIS + field survey and 2009 MALR statistics, the water budget which estimated according to field survey was 25 BCM and was 24 BCM when MALR statistics were used. This may be due to the accuracy of methodology which is used in the field survey. According to the present data, rice is the highest crop in water consumption; the water irrigation budget for rice was 9 BCM in 2008 field survey and decreased to 7.5 BCM in 2012 that may be the result of the reduction of cultivated area of rice according to the recommendations of decision makers in agricultural sector. Water budget of cotton was decreased rapidly from 5 BCM in 1980 to 1 $\mathrm{BCM}$ in 2008 due to the decrease in the cultivated land area and these results which are matching with the government were neglected for the importance of cotton production in the national income. Furthermore, Egyptian farmers do not prefer to cultivate cotton because of its' small cash return .On the contrary, the water budget for cotton increased again in 2012 and reached $1.4 \mathrm{BCM}$ which may be due to the governmental encouragement to increase the cotton cultivated area. Maize ranked the second crop in water budget after rice, because of the high importance of maize in food safety in Egypt.

Mainly, previous data show that Egypt is going to face a challenge in water resources, especially irrigation water. The water budget reached about 49 BCM during 2012 and 2013 seasons, due to the overlapping between crops and the use of cultivated lands more than once per year. Increasing land reclamation activities will increase the need for irrigation water. Therefore, we have two options to increase our food production; the first one is to find alternative water resources, such as ground water and the reuse of drained water. The second one is to change the crop pattern to achieve the maximum efficiency from available irrigation water budget. For example, we can replace some of the ricecultivated areas by maize crop because the second need less irrigation water. 
Table .5. Irrigation water budget (MCM) for cultivated area in summer survey

\begin{tabular}{|c|c|c|c|c|c|c|}
\hline Crops & $1980^{*}$ & $1990^{*}$ & $2000^{*}$ & $2009^{*}$ & $2008 * *$ & $2012^{*}$ \\
\hline Maize & 5144 & 5333 & 5264 & 4645 & 4316 & 4964 \\
\hline Sorghum & 973 & 757 & 918 & 790 & 527 & 800 \\
\hline Rice & 4922 & 5264 & 7964 & 6947 & 9178 & 7469 \\
\hline Sugar cane & 1526 & 1658 & 2245 & 2107 & 1988 & 1622 \\
\hline Cotton & 5136 & 4099 & 2139 & 1174 & 1028 & 1376 \\
\hline Tomato & 597 & 623 & 738 & 749 & 611 & 771 \\
\hline Other vegetables & 831 & 1994 & 2346 & 3239 & 3432 & 3549 \\
\hline Orchards & 1159 & 2063 & 3156 & 4484 & 3947 & 4378 \\
\hline Total & 20289 & 21791 & 24771 & 24136 & 25026 & 24929 \\
\hline
\end{tabular}

* Data calculated using cultivated area from MALR

** Data calculated using cultivated area from the GIS+ field survey data.

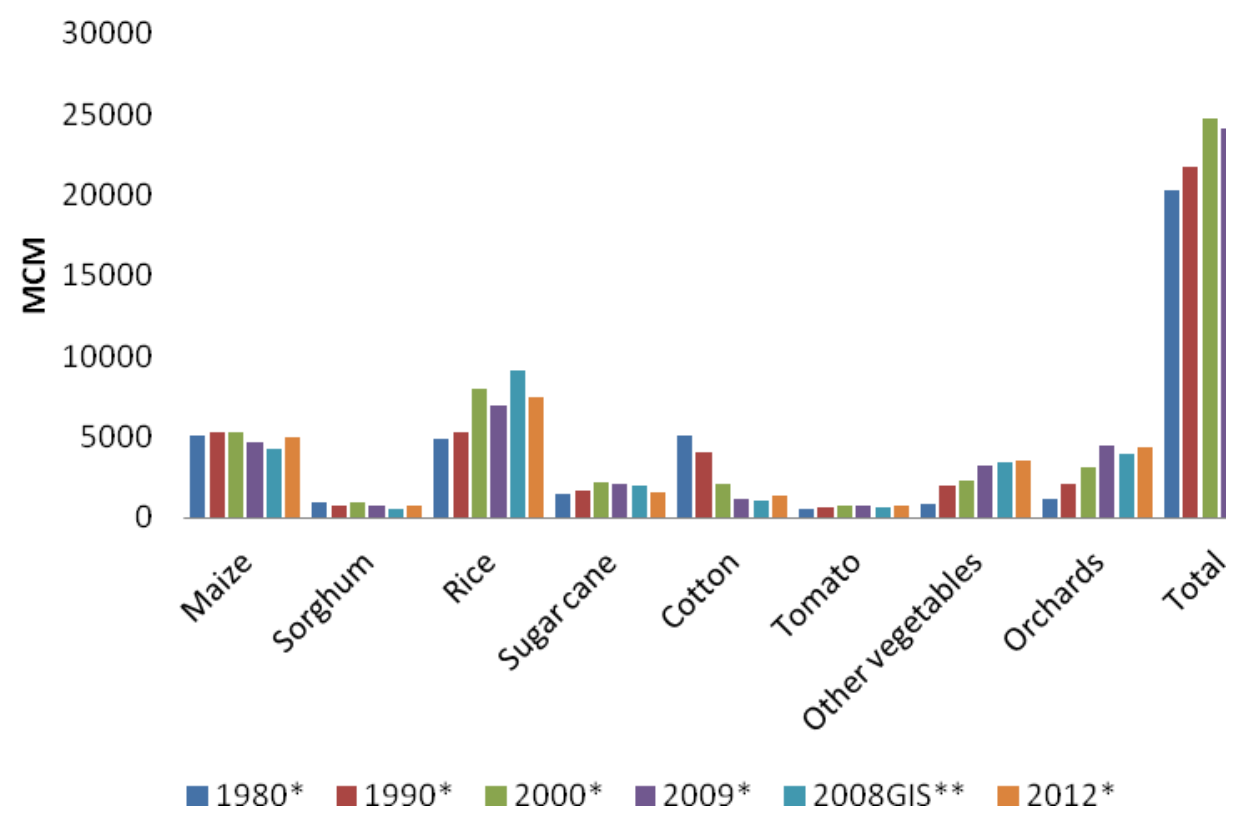

Figure 13. Water budget for cultivated area in Nile Delta and Valley from 1980 to 2012 summer

\section{Conclusion} survey

Nowadays, estimation of cultivated areas in the Egyptian Nile Delta and Valley by using GIS+ field survey technique is available in Egypt. Wheat and clover (barseem) represented the highest cultivated areas in winter survey; rice and maize were the highest cultivated area in summer survey. Water budget for cultivated crops in Nile Delta and Valley was estimated according to winter survey and reached $24 \mathrm{BCM}$ whereas, according to summer survey was $25 \mathrm{BCM}$. Consequently, we have to find alternative water resources to increase the cultivated area and reclaim new land for agriculture. Furthermore, we should change the crop patterns and find alternative crops which use a little amount of irrigation water.

\section{References}

Abou-Hadid, A. F., M. A. Medany, M.A. A. Abdrabbo, M. K. Hassanein, A. A. Farag, S. M Abolmaat, A. A Khalil, K. M. Refaie, S. M. Saleh, F. A. Hashem, A. A. Ismael, M. S. M. Ahmed, A. Kadah, T. Kadah; M. Kadah, A. T. El-Morsi, M. Bertin, G. Jaffrain, and A Elgueroua. (2010a) Preliminary Studies Using GIS and Field Survey to Determine Land Cover in Egypt. Arab Universities J. of Agri. Sciences. 18:229-236.

Abou-Hadid, A. F., M. A. A. Abdrabbo, A.A. Khalil and M. K. Hassanein. (2010b) Monitoring Land-Cover in the New Reclaimed Area: A Case Study in EL-Nubaria, Egypt. Nature and Science. 8(12) 
Allen, R.G., L.S. Pereira, D. Raes and Smith M. (1998) Crop evapotranspiration: Guidelines for computing crop requirements. Irrigation and Drainage Paper No. 56, FAO. Rome, Italy.

Canada Centre for Remote Sensing (2003) Principles of remote sensing. Centre for Remote Imaging, Sensing and Processing (CRISP) National University of Singapore.

http://www.crisp.nus.edu.sg/ research/tutorial/rsmain.htm

Cochran W.G. (1977) Sampling Techniques. Wiley 428pp. Common Problems. Meeting on Food and Agricultural Statistics in Europa, Conference of European Statisticians, Geneva, June 1999, paper n GE-9931347.

Dorigo WA, Zurita-Milla R, de Wit AJW, Brazile J, Singh R, Schaepman ME (2007) A review on reflective remote sensing and data assimilation techniques for enhanced agroecosystem modeling. International Journal of Applied Earth Observation and Geoinformation, 9: 165-193., doi: 10.1016/j.jag.2006.05.003

Egypt`s 2nd National Communication to the United Nations Convention on Climate Change. (2010)

Egypt National Competitiveness Council, Egyptian National Competitiveness Report. (2009)

El-Bagouri, I. H. M. (2008) Management of productive lands of Egypt: A presentation in IGBP Regional Workshop - MENA. 20- 21 November 2008, Cairo, Egypt.

EUROSTAT (2001) Manual of Concepts on Land Cover and Land Use Information Systems. Office for Publications of the EC, Luxembourg, theme 5: Agriculture and fisheries, Collection: Methods and nomenclatures, $106 \mathrm{p}$.

Fitzgerald GJ, Lesch SM, Barnes EM, Luckett WE (2006) Directed sampling using remote sensing with a response surface sampling design for site-specific agriculture. Computers and Electronics in Agriculture, 53: 98112., doi: 10.1016/j.compag.2006.04.003

Khalil, F., S. Ouda, N. Osman and A. Ghamis. (2011) Determination of agro-climatic zones in Egypt using robust statistical procedure. Fifteenth international water technology conference. IWTC-15, Alexandria, Egypt.

http://www.fao.org/nr/water/aquastat/main/index.stm

Mohamed, A. A. A., (2012) Environmental and demographical variations among Egyptian agricultural zones and their alternative uses in development of Egyptian agriculture, $\mathrm{PhD}$ thesis, agricultural economics department, faculty of agriculture, Ain shams University.

Quarmby, N. A., Milnes, M., Hindle, T. L., and Silleos, N., (1993) The Use of Multi-Temporal NDVI Measurements from AVHRR Data for Crop Yield Estimation and Prediction. International Journal for Remote Sensing. 14 (2): 199-210., doi: 10.1080/01431169308904332

Rogana J.; Chen, D., (2004) Remote Sensing Technology for Mapping and Monitoring Land- Cover and LandUse Change. Progress in Planning. 61, 301-325., doi: 10.1016/s0305-9006(03)00066-7 